exist in other organs is also hinted at. It would seem, therefore, to be worth while to investigate the state of the host a little more intently before performing vaccination.

\title{
REPERENCES
}

1. ADLER, A: (1940) -Arch. Neïrol. arid Psychiat., 44, 541.

2. BENEDICT, WM. (1942).-Atch. of Ophthal., 28, 988.

3. BRICKNER and BRILI (1941).-Arch. Neurbl. and Psychiat., 46, 16.

4. CogAN; D. (1945).-Arch. of Ophthal., 23, 144,

5. Davidof F, L. H. (1932).-Jl. Exper. Med., 55, 163.

6. Ferraro, A. (1944).-Arch. Neutol. and Psychiat., 52, 413.

7. FINLEY, K. H. (1937).-Arch. Neurol. and Psychiat., 37, 505.

8. Flexner, S. (1930).-Ji. Amer. Med. Asśoc., 94, 305.

9. Fol. Is and RICH (1943).-Bull. Johns Hopkins Hosp., 66, 106-122

10. FORD, F. R. (1928.)-Bull Johns Hopkins Hosp., 43, 140.

11. FrAN RIIN and BRICRNER (1947).-Arch. Neurot. and Psychiat., 58, 2, 125.

12. GranzmanN, E. (1927).-Schweiz. Med. Wöch., 57, 145.

13. GREENFIELD, J. G. (1929) -Brain, 52, 171.

14. HEATH, P. (1932).-Amer. Jl. Ophthal., 130.

15. KRIEDER, cited by FERRARO, A. and SchafFer, J. H. (1931).-Arch. Neurol. and Psychiat., 25, 570.

16. MADer, A., cited by Scheyling (1939).-Klin. Monatsbl. f. Augenheilk., 52, 223.

17. Marsden, J. P. and HuRst, E. W. (1932).-Brain, 53, 145.

18. MCALPINE (1947). -Brain, 69, 233-35.

19. MORRIson (1947).-Arch. Neurol. and Psychiat., 58, 391.

20. NeAL. J. B. (1942).-Enceph. Clin. Study, Grune and Stratton, N.Y., 137-261.

21. Putnam, T. J. (1939).-Arch. Neurol. and Psychiat.. 41, 1089.

22. Rucker (1945). - Jl. Amer. Med. Assoc., 127, 97.

23. Spielmeyer, W.-Zeitschr. $f$. d. ges. Neurol. and Psychiat., 118, 1 , $1928 ; 142,159,1932 ; 99,756,1925$.

24. VoN HERRENSCHWAND (1939).-Klin. Monatsbl. f. Augenheilk., 102, 815-23.

25. VoGT (1925). - Ji. Psychiat. and Neurol., 31, 245.

26. WoHLWILl, F. (1931).-Zeitschr. f. d. ges. Neurol. and Psychiat.; $26,322$.

27. ZAPPERT, and KAISR, M. (1935).-Zeitschr. f. Path., 48, 474.

28. Zeligs (1947). -Psych. Med.. 9, 110.

29. Grinker, R. R. (1944).-Neurol. Third edition. Thomas, Springfield, Ill.

\section{THE TREATMENT OF HYPOPYON ULCER OF THE CORNEA}

BY

\author{
E. H. CAMERON \\ EDINBURGH
}

THE problem of the infected corneal ulcer in miners has for many years been a serious one in Edinburgh and has been a cause of considerable loss̀ of vision and working capacity. About forty thousand miners are employed in the Lothians and Fife, and the great majority of the eye injuries which occur among them are treated in the Eye Department of the Royal Infirmary. For 
many years the number of cases of the so-called "hypopyon ulcer" did hot vary much, the average number of admissions per year to the writer's department, the charge of which he assumed in 1932, being about seventy-five. This figure represents about one half of the total number, as the Eye Department is a double one. Under the term "hypopyon ulcer" are included all corneal abrasions which show infiltration at the site of the injury with an inflammatory reaction, whether actual hypopyon is present or not. Two-thirds of the cases were miners, the remaining third consisting of workmen from other occupations with, in addition, a small senile group. Many of the cases did badly in spite of the employment of all forms of treatment then in use. In 1931 Dr. J. R. Paterson had read a paper at the Annual Congress of the Ophthalmological Society of the United Kingdom in which he reviewed 223 cases of traumatic infected corneal ulcer in miners, 182 of which had been treated in the Royal Infirmary. He used the records of cases that had been examined by his father, the late Dr. J. V. Paterson, in connection with claims for compensation. Of the total number, eighteen eyes were lost and only thirty-three retained vision of over $6 / 12$. In over fifty per cent., vision was reduced to less than $6 / 60$. The average stay in hospital was 29.4 days. These were deplorable results, and when, in 19.35, the W. H. Ross Foundation for the study of Prevention of Blindness was founded under the guidance of Dr. A. H. H. Sinclair, it was decided to try to improve matters, and work on the problem was begun in 1937. The bacteriological aspects of the problem were investigated by A. J. Rhodes working under Professor Mackie of the Bacteriology Department, but, although much valuable information was obtained, this work gave no help with regard to prognosis and treatment.

In 1939 experimental work on animals was begun by J. M. Robson and G. I. Scott; working under Professor A. J. Clark of the Pharmacology Department, and the results of their research suggested that one of the soluble sulphonamides; sodium sulphacetamide, which is very soluble and non-irritating, should be given a thorough clinical trial both in prevention and therapy. Colonel R. M. Dickson, the Director of the Ross Foundation, undertook to arrange for the preparation to be introduced as a first-aid treatment at the pit-head and in the ambulance-room, and the Ophthalmic Staff of the Royal Infirmary readily agreed to undertake the necessary clinical trials. The results of this work are embodied in a number of papers which have been collected in a volume recently published by the University of London Press entitled "The W. H. Ross Foundation (Scotland) for the study of prevention of blindness." To many ophthalmic surgeons interested in the subject this volume may not; however, be readily accessible, and a short article describing the progress made seems desirable. 
With the willing help of the colliery officials the first-aid treatment in the ambulance-room at the pit-head has been reorganised, and the danger of the neglect of apparently trivial eye injuries is now well understood by the officials and the miners themselves. When an eye injury is reported, sodium sulphacetamide in 10 per cent. solution is used as drops, and the miner is directed to continue to attend until danger of the development of serious trouble seems over. Any doubtful case is referred to his own doctor.

It has been the practice for many years to admit all cases of corneal abrasion coming to the Infirmary if they show evidence of even slight infection. These cases are all potential "hypopyon ulcers" and experience has proved the great danger of relying on out-patient treatment. From 1942 till March 1947 when the writer relinquished his charge, sodium sulphacetamide was used in routine treatment and almost entirely replaced other drugs. After penicillin came into general use it was given to supplement sodium sulphacetamide, but only in the now rarely occurring obstinate cases. More extensive use of it was made by Dr. C. W. Graham, who is in charge of the sister department, and his conclusions are given on page 20 of the Ross Foundation volume mentioned above. Sodium sulphacetamide was first used in 30 per cent. solution with consideràble success. Dr. H. M. Traquair suggested its use as a solid powder, and, as this proved non-irritating and most efficacious, the writer decided on the following scheme of treatment which is still the standard routine in the hands of his successor, Dr. J. R. Paterson. Atropine is given in the usual way two or three times a day, and the conjunctival sac is kept free from secretion by means of a simple lotion. Sodium sulphacetamide powder is applied by the sister-in-charge a number of times a day, even two-hourly if necessary, and during the night as well in severe cases. After lightly cocainising the eye she heaps some of the powder on the surface of the ulcer, using a small spoon or some other convenient instrument, and holds the lids apart until the powder has dissolved. The number of applications is diminished as improvement takes place, and in the end drops are 'substituted. The patient is not discharged until danger of further spread of the ulceration has ceased, and when he goes home he is directed to use atropine and sodium sulphacetamide drops during the remainder of his convalescence. Any other form of treatment is now rarely necessary, cauterisation, paracentesis, Saemisch section etc., being seldom indicăted.

Since 1942 only two eyes have been lost, one case being a shepherd in a poor state of health, and the other an elderly woman. In 1946, which may be taken as typical of the present position, the last complete year of the writer's charge, thirty cases were admitted, twentyone being miners. Six were from other occupations and three were 
senile cases. Of the twenty-one miners only three spent more than three weeks in hospital, and eight were in the ward for less than ten days. As a follow-up system in the case of miners who have returned to work is difficult to operate, there are records of vision in most cases only on their discharge. Four had vision of less than $6 / 60$, six of $6 / 36$ or better, and nine of $6 / 18$ or better. In two cases there was no record. No miner's eye has been lost since 1942, as compared with the ten per cent. lost in the series reviewed in 1931 .

It will be seen that during the last six years a great improvement has been brought about. In fact the method of treatment that has been adopted has altered the whole outlook with regard to hypopyon ulcers. A great deal of visual loss has been prevented, and the freeing of hospital beds that would otherwise have been occupied for long periods has been a great gain. It is possible that improvement in sanitation and working conditions in the pits has played its part, but the way in which the miners live has not greatly changed. Any alteration in the varieties of organisms that infect the cornea, or in their virulence, is improbable. It will be noted that the number of cases from other occupations has ${ }^{\bullet}$ diminished also, and in this connection it must be borne in mind that the same first-aid treatment as at the collieries is now used in many works and factories of the area served by the Royal Infirmary. The newer drugs too are used by the practitioner in his surgery, and in the treatment of most corneal abrasions in the hospital out-patient department, whether there is evidence of infection or not. The fact, too, that both practitioner and workmen are more alive to the dangers of slight injuries brings cases to hospital earlier than in past years. When all these points have been taken into account it remains true that we have now a simple and convenient method of treatment which makes success in dealing with the ordinary typical case of hypopyon ulcer practically certain. These cases are no longer regarded with the former dismay and apprehension. A few still do badly - those in older people, those whose admission has been delayed, those in which a deep infection of the cornea through a small puncture has taken place, and a few for no apparent reason. It has been found that, if the sodium sulphacetamide treatment fails to produce early and rapid improvement, penicillin and other forms of treatment are rarely of much more help.

I am indebted to Dr. A. H. H. Sinclair, Colonel R. M. Dickson, Dr. H. M. Traquair and the members of the Staff of the Eye Department of the Royal Infirmary for hetp in the preparation of this paper.

\section{REFERENCES}

Paterson, J. R. (1931).- " Notes on eye conditions in compensation cases in Scottish miners." Trans. Ophthal. Soc., 51.

The W. H. Ross Foundation (Scotland) for the Study of Prevention of Blindness (1948). University of London Press, Limited. 